\title{
Necrológio de Nicolas Tertulian ${ }^{1}$
}

Pierre Rusch ${ }^{2}$

O filósofo Nicolas Tertulian faleceu no último dia 11 de setembro [de 2019], em Suresnes (no Departamento francês de Hauts de Seine), aos 90 anos.

Nicolas Tertulian, cujo nome verdadeiro era Nathan Veinstein, nasceu em 1929 em Iasi, capital da Moldávia romena. Em julho de 1941, aos 12 anos, escapou por pouco do pogrom organizado pelas forças alemãs e pelo regime fascista colaboracionista de Ion Antonescu.

No final da II Guerra Mundial, ele frequentou o curso da Faculdade de Filosofia de Bucareste. Paralelamente, desenvolveu uma rica atividade de crítica literária, colaborando com revistas romenas de destaque. Desencorajado pelo marxismo dogmático que dominava a vida intelectual na Romênia comunista do pós-guerra, esforçou-se para fazer valer o direito de uma crítica independente, sensível à especificidade do material literário, mas fundado sobre bases teóricas sólidas. Tais esforços e determinações lhe renderam incontáveis humilhações por parte das autoridades, mas o levaram a dois autores de referência aos quais permaneceu vinculado pelo resto de sua vida: o italiano Benedetto Croce (1866-1952), mas, sobretudo, o húngaro György Lukács (1885-1971), sobre o qual se tornaria um dos grandes especialistas. Após tomar contato com Lukács, em 1965, manteve com ele uma forte relação pessoal, que durou até a morte do filósofo húngaro, em 1971. Desde então, consagrou grande parte de suas atividades à defesa e à exegese da obra lukacsiana.

O marxismo de Nicolas Tertulian se delineou através dessas duas referências. Um marxismo filosófico, fortemente ancorado em suas origens hegelianas, preocupado com a exploração de todas as fontes críticas de um sistema de pensamento aberto sobre o mundo e a história. Foi com este espírito de abertura que, em 1966, Tertulian encontrou Martin Heidegger em Friburgo, na Alemanha, e, depois de 1968, divulgou os escritos da Escola de Frankfurt (Adorno, Marcuse) para a Romênia.

Proibido de ensinar em 1977, Nicolas Tertulian se viu limitado a atividades de pesquisa até 1980, data em que decidiu deixar a Romênia. Depois de estadas em Heidelberg e em Siena, estabeleceu-se em Paris, onde obteve, em 1982, o posto de diretor de estudos associado à École des Hautes Études en Sciences Sociales (EHESS). Intelectuais tão pouco marxistas quanto François Furet (então presidente da EHESS) e Raymond

\footnotetext{
${ }^{1}$ Publicado originalmente no Le Monde, 25 sete. 2019. Trad. Pedro Corgozinho. Revisão ortográfico-gramatical de Vânia Noeli Ferreira de Assunção.

2 Tradutor e pesquisador da obra lukacsiana da Université Paris Dauphine. Publicou o livro L'Euvre monde: essai sur la pensée du dernier Lukács. Paris: Klincksieck, 2013.
} 
Aron, ou ainda Paul Ricoeur, desempenhariam um papel essencial para sua recepção na França - naturalmente, tanto quanto amigos próximos, tais como Olivier Revault d'Allonnes e Mikel Dufrenne. Uma intervenção do Ministro Claude Cheysson, vinda após uma grande mobilização de intelectuais franceses, permitiu que sua esposa, a escritora e tradutora Georgeta Horodinca (falecida em 2006), e seu filho se juntassem a ele em Paris.

O seminário de Nicolas Tertulian sobre a história do pensamento alemão moderno, mantido na EHESS durante quase 30 anos, foi um ponto de encontro e de debate essencial, onde íamos escutar Henri Lefebvre, Jacques d'Hondt, Xavier Tilliette, padre Marcel Régnier, Joseph Gabel ou Alexis Philonenko.

Paralelamente à sua atividade de professor, Nicolas Tertulian esteve energicamente engajado nos grandes debates travados a partir dos anos 1980: sobre o pós-modernismo, sobre as ligações de Heidegger com o nazismo, sobre o pensamento de Carl Schmitt. Suas contribuições substanciais, fundadas na leitura minuciosa dos textos, uma formação e erudição internacionais e uma visão clara sobre o que estava em jogo, permitiram-lhe participar dessas controvérsias com elementos determinantes. No fundo, delineava-se o projeto que também fora o de Lukács, em sua obra $A$ destruição da razão (1954): o de mostrar as relações entre o irracionalismo filosófico e certas evoluções antidemocráticas (sob o princípio lukacsiano de que "não existe visão de mundo “inocente"”).

Nicolas Tertulian foi por muito tempo o homem de um só livro: György Lukács: as etapas de seu pensamento estético, traduzido do romeno para o francês por F. Bloch (Paris, Le Sycomore, 1980)3. Em 2016, as Éditions de la Maison des Sciences de l'Homme publicaram uma autobiografia intelectual significativamente intitulada Pourquoi Lukács? (Por que Lukács?). Uma coletânea de artigos está em preparação pelas Éditions Klincksieck com o título de Modernité et antihumanisme (Modernidade e anti-humanismo) 4.

\footnotetext{
3 Em 2008 foi publicada uma tradução do francês para o português, feita por Renira Lisboa de Moura Lima, com apresentação de Ester Vaisman e Rainer Patriota pela Editora Unesp. [NT]

4 Por ocasião da publicação do presente necrológio na Verinotio, recebemos a notícia de que o livro foi publicado e se encontra à venda. A Editora Perspectiva de São Paulo publicou a mesma coletânea de artigos já em 2016. Pedro Corgozinho foi o tradutor para o português e Vitor Sartori cuidou da apresentação do livro. [NT]
} 
Como citar:

RUSCH, Pierre. Necrológio de Nicolas Tertulian. Verinotio - Revista online de Filosofia e Ciências Humanas, Rio das Ostras, v. 25, n. 2, pp. 12-4, nov. 2019.

Data de envio: 26 set 2019.

Data de aceite: 15 out 2019. 